\title{
Theoretical Background to the Role of Trust in Marketing
}

\author{
Annamária Zsigmondová ${ }^{1}$, Tibor Zsigmond ${ }^{2 *}$ and Renáta Machová $^{2}$ \\ ${ }^{1}$ Univerzita J. Selyeho, Fakulta ekonómie a informatiky, Katedra ekonomiky, Bratislavská cesta \\ 3322, Komárno, 94501, Slovenská Republika \\ ${ }^{2}$ Univerzita J. Selyeho, Fakulta ekonómie a informatiky, Katedra manažmentu, Bratislavská cesta \\ 3322, Komárno, 94501, Slovenská Republika
}

\begin{abstract}
The aim of the study is to present the theoretical background of trust and to review its role in marketing among the disciplines mentioned in the article. After the methodological definition, the article provides the reader with a complex overview of the concept of trust in the national and international literature. The need for trust extends to business and market interactions throughout the supply and value chain, as they are interrelated in all areas of production and service. In addition, its existence also plays an important role in online commerce, the lack of which is understood by companies and intermediaries in the reduction of transaction costs and reputation. However, the question arises as to whether trust can be so easily delineated. Is the decision of whether or not to trust the other a simple question to be decided to which there is a clear answer?
\end{abstract}

\section{Introduction}

Consumer behaviour is becoming a vital aspect of customer relationships and marketing strategy. As several studies have pointed out, building consumer confidence is key to longterm success of retailers. However, one of the negative aspects of this is the fear about products and manufacturers.

The role of efficiency is a crucial factor in the private sector. Trust as a prerequisite for successful cooperation is an essential aspect between the actors. We talk about interaction, when the parties pass the uncertainty threshold and balance their intentions. Bilateral trust between the actors is also a kind of "guarantee", as it is supporting achieving the goals. In order to achieve our goals we are put into situations when dependence on others is essential. The consumers nowadays are more consumption-oriented, therefore they also have to rely on others, especially businesses.

The study begins with general definition of trust, which is followed by detailed definition of the term in corporate context and in terms of PR. A chapter of this study is addressing the issue of trust in terms of marketing as well. The chapter emphasizes the importance of trust: developing, maintaining and consequences of trust between the individual market players, i.e. companies and consumers. In this regard, we considered it

\footnotetext{
* Corresponding author: zsigmondt@ujs.sk
} 
important that the study provide a deeper insight into processing the topic, thus also focusing on the theoretical background of consumer confidence. In addition, the field of ecommerce has also reflected on trust, mistrust and its consequences, as well as its impact on businesses and consumers. At the end of the study a conclusion is provided summarizing the findings.

\section{Aims and methodology}

The aim of the publication is to examine the role of trust in marketing from the point of view of customer and the business. In order to achieve this goal, the study summarizes the most relevant findings of scientific literature sources. It deals with conceptual definitions of trust and then focuses on business relationships in marketing terms. In consumer society, the development of mistrust is becoming stronger, which is detected on domestic and international level as well. The phenomenon is also reflected in relationship marketing. One of the basic pillars of trust in the field of e-commerce and brick-and-mortar shopping is brand building as a prerequisite of customer action. Both mistrust and reliability are important aspects in terms of the customer. The customer can trust the brand or product, but might have doubts about the intermediary. Satisfaction with online store can also influence the customer trust, which has impact on customer determination to buy the product. The end of the study provides a short conclusion, summarizing the perspective of consumer and the service provider. approached from the provider and consumer side.

\section{Theoretical background}

\subsection{The concept of trust}

The concept of trust has to be approached interdisciplinary. It had been studied from the perspective of economics, psychology, sociology and law, but all the mentioned sciences approach the concept of trust from different perspective.

The success of knowledge-based organizations heavily depends on trust. In the case of mistrust, there would not be an effective communication, compatible teamwork, as well as the organizational culture would not function properly. In recent years, the importance of trust has had a major impact on daily life of organizations. Many studies and authors have addressed the issue. Culture is changing as a result of development of modern technologies. Different lifestyles and diversity of value systems require a more sophisticated level of cooperation and interdependence. Czakó [1] found that increased cooperation with the individual influences the level of trust as well. This is reflected in a phenomena how companies adopt to market changes and challenges. Smart devices make the communication effective as well as they introduce some controversial aspects. They enable the efficient flow and exchange of knowledge, but also raise the question of trust and anonymity.

Piotr Sztompka (1999) identified several alternatives for the emergence of trust. Trust may appear only with one of the individuals or in the case when one of the individuals develops an intrinsic motivation to develop trust, as it is necessary to initiate a contact with the other individual. A culture of trust can also be formed, which consists of interrelated values and norms [2]

The concept of trust also plays a significant role in business. Stephen [3] introduces trust as a hidden factor. He is convinced that trust is present in every moment and in all areas of life. The existence of trust strengthens the human relationships, makes communication more efficient, and can improve the quality of organizations. Increasing 
trust might result in achievement of long-term company goals.

Sajfert et al. [4] describe the importance of trust in the company as a key to employee cooperation and growth. Trust invested into employee-employer cooperation will determine the corporate atmosphere and intergroup cooperation. As a direct result, efficiency to achieve organizational goals will increase. Disagreements, lack of cooperation and adaption, changes in attitude to innovation, strict group stereotypes emerge as a result of mistrust. This type of behaviour creates unfavourable company atmosphere.

\subsection{Trust in the market}

Trust is the key element of marketing concept. Every relationship based on success depends on the degree of trust between people. Thus, the primary goal of marketing is to satisfy the customer need, maintain and manage the relationship with the customer and deliver promises. Trust is an essential element to achieve these goals.

Trust is a complex behavioural attitude that develops as a multidimensional overlap between the market participants. Trust is a simple spectrum, from established trust to distrust [5].

Trust cannot be built explicitly on direct experience as it would contradict to traditional human values and marketing definitions. However, consumers can prefer the recommendations of a third party in their final decision. Thus, trust can be built on both direct and indirect experiences, provided that the indirect source itself is reliable. People tend to direct their attention to negative experiences conveyed, thus generating contradiction about their own competence. At the same time, most people are unlikely to be aware of this and they set up several trust dilemmas. Expressing opinion can often be seen as an output rather than input to marketing models, so the relative impact of direct or indirect experience on development of trust may be an objective of further research [6].

White argues that conscious positive intentions are the foundations of trust [7]. The hypothesis of Garbarino and Lee are based on a fact that social relations are fundamentally based on benevolence, i.e., the parties do not ignore each other's interests [8]. This kind of behaviour is later reflected in developing organizational structure, as well as it is a determining factor of relationship. Product portfolio and security are part of the corporate structure, while the appropriate incentives and support are related to public relations. Companies should behave if they were the customers themselves expecting a certain behaviour from the company [9].

Trust and mistrust have influence on the behaviour of market participants, including intention and development of future relationships. If one of the participants experiences a negative perception of building trust, the level of cooperation and commitment will decrease [10]. Decreasing level of trust is also reflected in opportunistic behaviour. Initiating a cooperation requires components that will result in development and increase in trust. To Relationship commitment is one of these factors. If one of the parties is generating trust accepting also the vulnerability, while the other party meets the obligation, they have already lay down the cornerstone of trust [11]. It can be assumed that trust is a relevant component of relationship between the parties. [12]. Palmatier, in a paper published more than a decade later, also mentioned that the higher the level of trust, the more committed it can make the consumer [13].

A long-term and fruitful relationship without trust is almost unimaginable. Since customers are in contact with each other, the behaviour of salespeople affects the future confidence of consumers, in which the service provider's further behaviour also plays a role. Increasing level of trust has a direct impact on building long-term relationship which will result in reduction of transaction costs [14]. In the case of online shopping, the brand requires reliability from the online retailer and the information system, through which the 
transaction takes place. If it is not managed properly, the customer can trust the brand but cannot trust the intermediary (e.g., the Internet). Lewicki et al. [15] and Arnott [16] researched the interaction of trust-related decisions in online context. As a result of ecommerce development, there is a growing need for knowledge and theories about the online consumer behaviour as it is becoming a vital aspect of customer relationships and marketing strategy [17]. Online shopping behaviour needs to be understood [18], and therefore attracts increasing attention of scientists and researchers [19]. As several studies have pointed out, the key to the long-term success of e-retailers is to build consumer confidence [20-22].

\subsection{Consumer trust}

The aspects of trust had been addressed by several scientific studies in different field of research i.e. economics, management, technology, social studies, psychology and consumer behaviour [23]. Trust is based on the buyer's expectations that the seller will behave in a reliable, ethical and socially appropriate manner, fulfilling the obligations of the buyer, despite the buyer's vulnerability and dependence [24]. Thus, consumer reliability considerations are likely to determine the final purchasing decision between the buyer and seller [25]. Li et al. [26] found that trust is even more important in the case of e-commerce as consumers experience greater risk since they cannot visit brick-and-mortar outlets to have personalized experience and see and touch the products they are intended to buy. It plays a crucial role in determining online shopping intent [27] and purchasing decision [28]. Trust is also a key factor to build customer loyalty and developing strong and lasting relationships between the buyers and sellers [29]. Lack of trust is the biggest barrier of online transactions. s [30]. When negative shopping experience occurs, buyers generate a negative attitude [31], no longer trust the seller, and are likely to turn to further alternatives to meet their needs and desires [32].

Consumer confidence is built on experience, which takes time to develop. It also has a key role in reducing tensions and conflicts, supporting the flow of information, being able to create greater coherence, and also contributing to realization of future transactions [33]. Consumer trust can also be interpreted as a kind of behavioural goal, as a skill to rely on a business partner. Thus, the presence of one party's trust in the reliability and honesty of the other party $[11,12,34]$ can lead to positive expectations.

Trust generates a kind of effect among the existing or future partners, a kind of "hope" that the other party does not take advantage of the other party's vulnerability [35]. It is a long and strong relationship that helps to shape the vision of the parties. It contributes to overcome uncertainty and reducing risks $[29,35]$, initiates balanced relationships, and thus influences the success of firms [36].

In his research, [7] directed the attention to three factors contributing to the development of consumer confidence. These are the following:

$>$ trust,

$>$ problem solving ability,

$>$ loyalty.

Trust means competent expertise in terms of the service provider and a willingness to accept it from the consumer's aspect. Trust based on expertise includes the following three components: knowledge, ability and inclination to skill [7]. In addition to the factors listed, [10] mentions capacity, followed by professional competence and know-how [37]. Trust on the consumer side is a central component that plays a key role in the effectiveness of an organization. It is important to emphasize, that at the same time it is present as a lower risk factor, thus ensuring the feeling of mutual loyalty [29]. Doubting and terminating customer relationship usually happens due to mistrust [38]. 
Another dimension of consumer confidence is the willingness to solve the problem. The precondition is that all the problems encountered in different phases of the service must show a willingness to be solved. The effect of this will be extended to the management within the service company as well as will increase the consumer confidence. However, it is important to emphasize that the arising problems will offer important opportunities for companies to demonstrate commitment [39]. Overall, it is a constructive relationship in which the service company is detecting the problem and feels motivated to communicate and solve it for the benefit of customer. Reducing risks strengthens consumer cooperation, so the level of cooperation will increase. The service provider thus creates a sustainable relationship based on trust, which is essential to develop customer loyalty [34].

Another important factor in building trust is loyalty. From customer perspective, loyalty is a favourable response for the product portfolio offered by the service provider within a defined period of time. Brand loyalty is closely linked to regular purchase realized by the customer. When defining loyalty, attitude characteristics are essential. It is a strong and intense commitment of the customer, a kind of intention to repeat a purchase [35, 40-42]. In order to maintain the relationship, it generates a viewpoint that involves resistance to various situational factors and also the resistance to competitors' marketing efforts [42, 43].

Because the existence of consumer trust plays a significant role not only in brick-andmortar shopping but also in e-commerce, online retailers place significant emphasis on consumer trust [44]. Examining the relevance of trust and intent to buy, Komiak and Benbasat [45] concluded that cognitive trust (which focuses on consumer beliefs based on rational expectations of online retailers 'characteristics) affects emotional trust (which affects consumer attitudes and emotions), which further influences the intention to purchase. Moreover, the level of trust of customers exposed to inconsistent product information and reviews significantly influences their purchase intention [46]. As a result, the critical role of trust in determining consumers' purchasing intentions is influenced by satisfaction with products and online stores [47-48]. If retailers want consumers to buy their products, they must go beyond the threshold of reliable behaviour [49-50].

\section{Conclusions}

The aim of the study was to present the theoretical background of trust, focusing on its role in marketing, and to emphasize its importance for market players. The authors present the general definition of trust and an overview of research results in the past few decades. Each sub-chapter of the study focuses on a more targeted area of trust, addressing the issue from the perspective of businesses and customers. Trust is a kind of relationship based on experience, but it is also a cornerstone of building customer relationship. It takes time to develop, while a negative experience is enough to ruin trust. It contributes to reducing the costs of manufacturers and service providers. The research presented in this study suggests that trustful business relationships result in greater profits, customer satisfaction, and flexibility. However, it is important to examine other dimension as well, as business relationships are under constant threat due to uncertainty, complexity, specialization, information barriers, etc. It should be emphasized that appropriate advertising can change consumer attitudes towards a particular product and reduce perceptions of product risk. Both direct and indirect marketing can play an important role in consumer decision-making. Direct marketing initiatives have a greater impact on purchasing decisions than mediabased methods such as television, radio, and printing. In addition, marketing can significantly influence the consumer awareness about the product performance and ultimately determine the likelihood of the purchase. Product performance and quality are also related to brand building.

E-commerce, as a most affected field nowadays can be characterized by mistrust 
factors. In e-business environment, businesses have to deal with inappropriate behaviour, identity fraud, and the misuse of personal data. The development of the reliability of online transactions is significantly influenced by branding considerations, as these are key factors in minimizing the risks faced both by products and web manufacturers. As e-commerce is facing higher risks trust is more important for online than offline retailers. In addition, retailers (but certainly not just them) need to focus mainly on direct marketing campaigns, as they have a greater influence on development of risk in online environment. Detailed and accurate product information, acceptable prices for the customer and the consumer's expectation of a favourable purchase can further increase online sales. Companies that sell their products online have to be aware that trustful intermediaries (web sellers) can increase the quality of products they sell. Accordingly, high-quality products are likely to help reduce online uncertainty, increase trust in intermediaries selling these products, and reinforce the feeling that e-channels take care of their users and understand their specific needs.

\section{References}

1. Czakó Á. Szervezetek, szerveződések a társadalomban. Budapest: BCE Szociológia és Társadalompolitika Intézet (2011)

2. Szabó I. L. Az intézményi, szervezeti bizalom helyzete Magyarországon. Nemzet és biztonság, 3, 3 (2014)

3. Stephen M.R.C. The Speed of Trust: The One Thing That Changes Everything. USA: Free Press (2008)

4. Sajfert, D., Nikolić, M., Vukonjanski, J., Terek, E., Vulović, M. The Impact of Ethical Leadership Behavior on Communication Satisfaction and Organizational Earning in Companies in Serbia. Acta Oeconomica Universitatis Selye, 8, 1 (2019)

5. Mari S. Does Trust Improve Business performance? Oxford: Oxford University Press (2000)

6. Horecký, J. Operation and action of a trade union (in terms of Czech Republic labour law). Central European Journal of Labour Law and Personnel Management, 1, 1 (2018)

7. White, T. B. Consumer Trust and Advice Acceptance: The Moderating Roles of Benevolence, Expertise, and Negative Emotions. Journal of Consumer Psychology, 15, $2(2005)$

8. Garbarino, E., Lee, O. F. Dynamic Pricing in Internet Retail: Effects on Consumer Trust. Psychology \& Marketing, 20, 6 (2003)

9. Mitchell, A. Building consumer trust is the secret of success. Marketing Week, 28, 19 (2005)

10. Cho, J. The mechanism of trust and distrust formation and their relational outcomes. Journal of Retailing, 82, 1 (2006)

11. Morgan, R. M., Hunt, S. D. The commitment-trust theory of relationship marketing. Journal of Marketing, 58 (1994)

12. Moorman, C., Zaltman, G., Deshpande, R. Relationships between providers and users of market research: the dynamics of trust within and between organizations. Journal of Marketing Research, 29, 3 (1992)

13. Palmatier, R. W., Jarvis, C. B., Bechkoff, J. R., Kardes, F. R. The Role of Customer Gratitude in Relationship Marketing. Journal of Marketing, 73, 5 (2009) 
14. Doney, P. M., Cannon, J. P. An examination of the nature of trust in buyer-seller relationship. Journal of Marketing, 61, 2 (1997)

15. Lewicki, R. J., Mcallister, D. J., Bies, R. J. Trust and distrust: new relationships and realities, Academy of Management Review, 23, 3 (1998)

16. Arnott, D. C. Conceptualizing trust. Academy of Marketing Conference, (2005)

17. Close, A. G., Kukar-Kinney, M. Beyond buying: motivations behind consumers online shopping cart use. Journal of Business Research, 63, 9-10, (2010)

18. Herrero, A., San Martin, H. Effects of the risk sources and user involvement on ecommerce adoption: application to tourist services. Journal of Risk Research, 15, 7 (2012)

19. Mosteller, J., Donthu, N., Eroglu, S. The fluent online shopping experience. Journal of Business Research, 67, 11 (2014)

20. Suh, B., Han, I. The impact of customer trust and perception of security control ont he acceptance of electronic commerce. International Journal of Electronic Commerce, 7, 3 (2003)

21. Pavlou, P. A., Fygenson, M. Understanding and predicting electronic commerce adoption: an extension of the theory of planned behavior. MIS Q. 30, 1 (2006)

22. Vos, A., Marinagi, C., Trivellas, P., Eberhagen, N., Skourlas, C., Gianna, G. Risk reduction strategies in online shopping: e-trust perspective. Procedia Social and Behavioral Sciences, 147, 25 (2014)

23. Kim, D. J., Donald, L. F., Rao, H. R. A trust-based consumer decision-making model in electronic commerce: the role of trust, perceived risk and their antecedents. Decision Support Systems, 44, 2 (2008)

24. Gefen, D., Karahanna, E., Straub, D.W. Trust and TAM in online shopping: an integrated model. MIS Q. 27, 1 (2003)

25. Gupta, P., Yaday, M. S., Varadarajan, R. How task-facilitative interactive tools foster buyers' trust in online retailers: a process view of trust development in N. Pappas. Journal Retailing, 85, 2 (2009)

26. Li, H., Jiang, J., Wu, M. The effects of trust assurances on consumers' initial online trust: a two-stage decision-making process perspective. International Journal of Information Management, 34, 3 (2014)

27. Hong, I. B., Cha, H. S. The mediating role of consumer trust in an online merchant in predicting purchase intention. International Journal of Information Management, 33, 6 (2013)

28. Buttner, O. B., Goritz, A. S. Perceived trustworthiness of online shops. Journal of Consumer Behaviour., 7, 1 (2008)

29. Santos, C. P. dos, Fernandes, D. von der H. Antecedents and Consequences of Consumer Trust in the Context of Service Recovery. Brazilian Administration Review, 5, 3 (2008)

30. Urban, G.L., Amyx, C., Lorenzon, A. Online trust: state of the art, new frontiers, and research potential. Journal of Interactive Marketing, 23, 2 (2009)

31. Gao, L., Bai, X. Online consumer behaviour and its relationship to website atmospheric induced flow: Insights into online travel agencies in China. Journal of Retailing and Consumer Services, 21 (2014)

32. Lee, Y. Impacts of decision-making biases on eWOM retrust and risk-reduching strategies. Computers in Human Behavior, 40 (2014) 
33. Dwyer, F. R., Schurr, P. H., Oh, S. Developing buyer-seller relationships. Journal of Marketing, 51, 2 (1987)

34. Sirdeshmukh, D., Singh, J., Sabol, B. Consumer Trust, Value, and Loyalty in the Relational Exchanges. Journal of Marketing, 66, 1 (2002)

35. Aydin, S., Özer, G., Arasil, Ö. Customer loyalty and the effect of switching costs as moderator variable. Marketing Intelligence \& Planning, 23, 1 (2005)

36. Johnson, D., Grayson, K. Cognitive and affective trust in service relationships. Journal of Business Research, 58, 4 (2005)

37. Blomqvist, K. The Many Faces of Trust. Scandinavian Journal of Management, 13, 3 (1997)

38. Harding, R. The Street-level Epistemology of Trust. Politics \& Society, 21, 4 (1993)

39. Benda-Prokeinová, R., Dobeš, K., Mura, L., Buleca, J. Engel's Approach as a tool for estimating consumer behaviour. E \& M Ekonomie a Management, 20, 2 (2017)

40. Dick, A. S., Basu, K. Customer loyalty: towards an integrated conceptual approach. Journal of the Academy of Marketing Science. 22, 2 (1994)

41. Lichtlé, M-C., Plitchon, V. Understanding better consumer loyalty. Recherche at Applications en Marketing, 23, 4 (2008)

42. Oliver, R. L. Whence Consumer Loyalty? Journal of Marketing, 63, 4 (1999)

43. Bandyopadhyay, S., Martell, M. Does attitudinal loyalty influence behavioural loyalty? A theoretical and empirical study. Journal of Retailing and Consumer Services, 14, 1 (2007)

44. Park, J., Gunn, F., Han, S.L. Multidimensional trust building in e-retailing: crosscultural differences in trust formation and implications for perceived risk. Journal of Retailing and Consumer Services, 19, 3 (2012)

45. Komiak, S. Y. X., Benbasat, I. Understanding customer trust in agent-mediated electronic commerce, web-mediated electronic commerce, and traditional commerce. Information Technology and Management, 5, 1-2 (2004)

46. Zhang, K. Z. K., Cheung, C. N. K., Lee, M. K. O. Examining the moderating effect of inconsistent reviews and its gender differences on consumers' online shopping decision. International Journal of Information Management, 34, 2 (2014)

47. $\mathrm{Wu}, \mathrm{I}$. L. The antecedents of customer satisfaction and its link to complaint intentions in online shopping: an integration of justice, technology, and trust. International Journal of Information Management, 33, 1 (2013)

48. Csíki, O., Horváth, R., Szász, L. A Study of Regional-Level Location Factors of Car Manufacturing Companies in the EU. Acta Oeconomica, 69, S2 (2019)

49. Bente, G., Baptist, O., Leuschner, H. To buy or not to buy: Influence of seller photos and reputation on buyer trust and purchase behaviour. International Journal of Human - Computer Studies, 70, 1 (2012)

50. Bakó, F., Szemerédi, E. Kutatói szeminárium a Széchenyi István Egyetemen: „Családok - generációk - vállalkozások - dilemmák” mühelykonferencia beszámoló. Tér-Gazdaság-Ember, 6, 3 (2018) 